\title{
(C) OPEN ACCESS \\ Cortical subarachnoid haemorrhage with reversible cerebral vasoconstriction syndrome in an elderly woman
}

\author{
Yoshihiko Chiba, Daisuke Yamamoto, Tsuyoshi Uchiyama
}

Department of Neurology, Seirei Hamamatu General Hospital, Hamamatsu, Shizuoka, Japan

\section{Correspondence to} Dr Daisuke Yamamoto, daisuke-yama@sis.seirei.or.jp

Accepted 21 February 2017

CrossMark

To cite: Chiba $Y$, Yamamoto D, Uchiyama T. BMJ Case Rep Published online: [please include Day Month Year] doi:10.1136/ bcr-2017-219319

\section{DESCRIPTION}

A woman aged 65 years had a sudden onset of severe headache after swimming. She had prolonged headache; therefore, she presented at the emergency department. During the examination in the emergency department, her physical and neurological examinations were unremarkable. Haematological findings were normal. The CT scan of the head revealed a cortical subarachnoid haemorrhage (cSAH) in the right frontal and left temporal lesion (figure 1A, B). The cerebrospinal fluid analysis revealed normal protein and cell counts. A brain MRI showed only high-intensity changes for cSAH with no findings of microbleeds (figure 1C, D). The magnetic resonance angiography (MRA) showed mild stenotic changes on the right posterior cerebral artery (PCA) (figure 2A). There was no evidence of any aneurysm. Based on the constriction findings, reversible cerebral vasoconstriction syndrome (RCVS) in conjunction with cSAH was suspected, and intravenous nicardipine was initiated followed by oral lomerizine in the same way as previously reported. ${ }^{1}$ On day 9 , the MRA showed findings of systemic constriction which were particularly

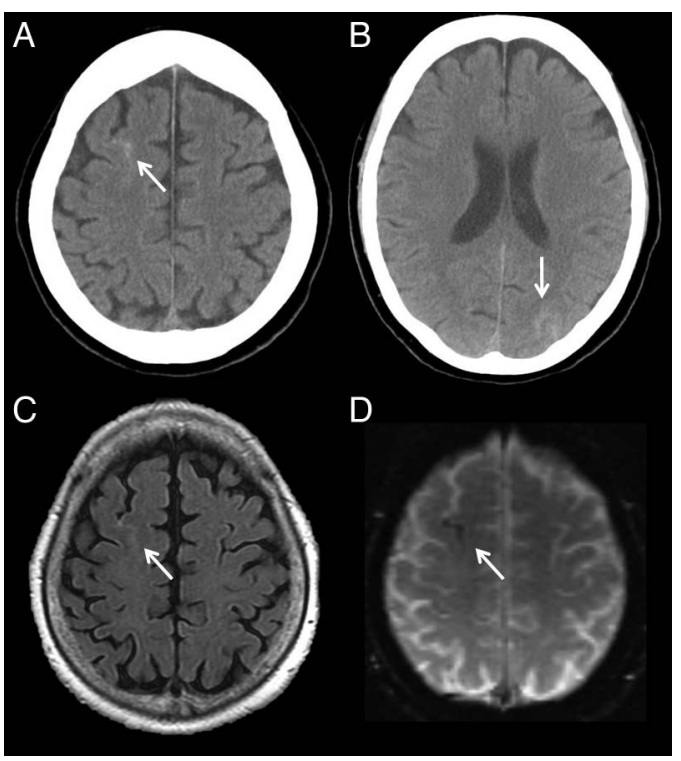

Figure 1 ( $A$ and $B$ ) CT of the head reveals a mild cortical subarachnoid haemorrhage (CSAH) in the right frontal and left temporal lesion (arrow). (C and D) Brain MRI on admission shows high-intensity changes for CSAH on fluid-attenuated inversion recovery imaging and low-intensity changes on gradient echo $12^{*}$-weighted imaging (arrow).

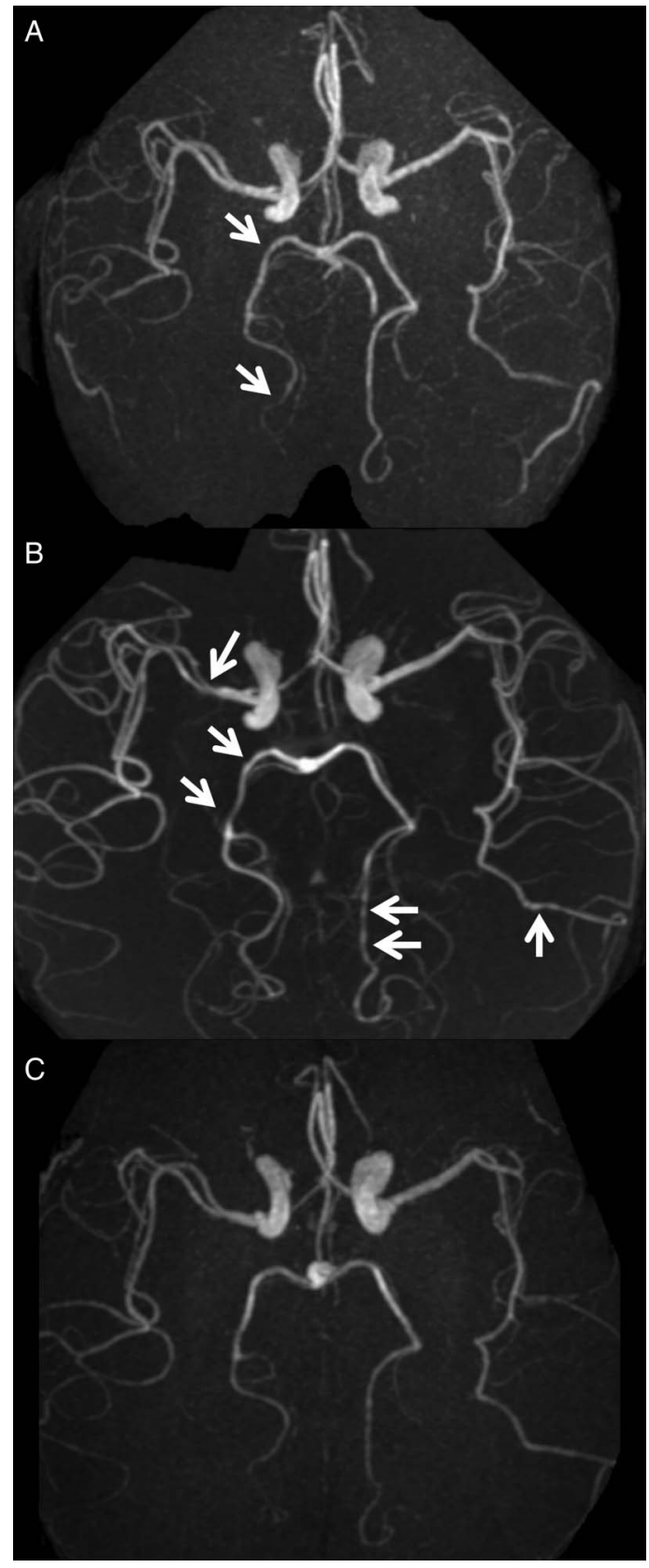

Figure 2 (A) The magnetic resonance angiography (MRA) on admission shows mild segmental stenotic changes in the right posterior cerebral artery (PCA) (arrow). (B) The MRA on day 9 shows the findings of systemic constriction, which are particularly prominent in the right middle cerebral artery and left PCA (arrow). (C) The MRA on day 27 shows improvement in the constriction findings. 
emphasised in the right middle cerebral artery and the left PCA (figure 2B). On day 27, the constriction findings had improved (figure 2C). The reversible vasoconstriction findings were consistent with RCVS. RCVS and cerebral amyloid angiopathy (CAA) are common aetiologies of atraumatic cSAH. ${ }^{2}$ In younger patients, RCVS is the most common cause of cSAH, and CAA should be considered in older patients, especially in those over 60 years of age. ${ }^{23}$ It is unusual that a relatively elderly woman would develop a cSAH with RCVS; however, we should consider the possibility of RCVS, although the patient may not be young.

\section{Learning points}

- Reversible cerebral vasoconstriction syndrome (RCVS) is the most common cause of cortical subarachnoid haemorrhage (CSAH) in younger patients. Cerebral amyloid angiopathy is the most common cause in elderly patients, particularly those older than 60 years of age.

- However, there have been a few reports in which a case of RCVS presented with CSAH in patients over 60 years of age; therefore, we should consider the possibility of RCVS even though the patient is not young.
Contributors YC was a major contributor in writing the manuscript. DY and TU also treated the patient, and interpreted the patient data. All authors read and approved the final manuscript.

Competing interests None declared.

\section{Patient consent Obtained.}

Provenance and peer review Not commissioned; externally peer reviewed.

Open Access This is an Open Access article distributed in accordance with the Creative Commons Attribution Non Commercial (CC BY-NC 4.0) license, which permits others to distribute, remix, adapt, build upon this work non-commercially, and license their derivative works on different terms, provided the original work is properly cited and the use is non-commercial. See: http://creativecommons.org/ licenses/by-nc/4.0/

\section{REFERENCES}

1 Ueki $H$, Sanayama $Y$, Miyajima $A$, et al. Reversible cerebral vasoconstriction syndrome promptly diagnosed with magnetic resonance imaging including magnetic resonance angiography during immunosuppressive therapy in a 16-year-old girl with refractory cytopenia of childhood. Hematol Rep 2016; 8:6673.

2 Graff-Radford J, Fugate JE, Klaas J, et al. Distinguishing clinical and radiological features of non-traumatic convexal subarachnoid hemorrhage. Eur J Neurol 2016;23:839-46.

3 Kumar S, Goddeau RP Jr, Selim MH, et al. Atraumatic convexal subarachnoid hemorrhage: clinical presentation, imaging patterns, and etiologies. Neurology 2010;74:893-9.

Copyright 2017 BMJ Publishing Group. All rights reserved. For permission to reuse any of this content visit

http://group.bmj.com/group/rights-licensing/permissions.

BMJ Case Report Fellows may re-use this article for personal use and teaching without any further permission.

Become a Fellow of BMJ Case Reports today and you can:

- Submit as many cases as you like

- Enjoy fast sympathetic peer review and rapid publication of accepted articles

- Access all the published articles

- Re-use any of the published material for personal use and teaching without further permission

For information on Institutional Fellowships contact consortiasales@bmjgroup.com

Visit casereports.bmj.com for more articles like this and to become a Fellow 